E Q U I L I B R I U M

2 ( 5 ) 2010

ISSN 1689-765X

Michał Ptak

\title{
Directions of Changes in the Functioning of Economic Instruments for the Environmental Policy in Poland
}

Key words: environmental policy, economic instruments for environmental policy, environmental taxes and charges, emission trading system

\begin{abstract}
Environmental policy instruments allow incorporating the problem of using the natural resources into the decision-making process of individual agents. One of the most efficient instruments for environmental protection are economic instruments, the indirect methods of influencing agents' behaviour. The aim of the article is to present the state of the Polish system of economic instruments in the light of other European countries' experiences (especially the European Union countries) and prospects for the use of economic instruments in the environmental policy during the oncoming years. The study is based on a subject literature review, reports ordered by the Polish Ministry of Environment and publications published by The Organisation for Economic Co-operation and Development (OECD) and the European Environment Agency (EEA). The analysis suggests that economic instruments are widely used in the Polish environmental policy. The main economic instruments in this policy are environmental charges and fines. Some of these charges and fines have been used in the Polish environmental policy for several dozen years. Revenues from these instruments are earmarked for environmental expenditures. There are also some new, interesting economic instruments applied in the Polish environmental policy, such as: depositrefund systems, tradable energy certificates and emissions trading scheme. There are some opportunities for expanding the use of economic instruments for the environmental policy in Poland. For example, there could be increased the use of some environmental charges or taxes, and the environmental insurance. Poland could also implement an environmental tax reform.
\end{abstract}

\section{INTRODUCTION}

Environmental policy instruments (tools) allow incorporating the problem of using the natural resources into the decision-making process of individual agents. One of the most efficient instruments in environmental protection are economic instruments, the indirect methods of influencing agents' behaviour. 
The aim of the article is to present the state of the Polish system of economic instruments in the light of other European countries' experiences (especially the European Union countries). Particular attention is paid to the changes that have occurred in this system in recent years. These changes and developments assimilated the Polish system of economic instruments with the other systems applied in the European Union member countries. Some of these changes were designed to incorporate the Community law. The remainder of the article includes desirable developments in the functioning of economic instruments for the environmental policy in Poland.

\section{THE NATURE AND TYPES OF ECONOMIC INSTRUMENTS USED IN ENVIRONMENTAL PROTECTION}

According to the most frequently cited definition, environmental policy tools can be labelled as 'economic' when they affect estimates of the costs and benefits of alternative actions open to economic agents. As a result of their use agents select those actions that lead to a more desirable situation from environmental standpoint. These instruments are often contrasted with the command and control policy approaches which directly regulate polluters' behaviour through the use of specific requirements (mainly orders and bans) (Śleszyński, 2000, p. 190). In the case of economic instruments, relevant incentives are transmitted through the market that is why these instruments are classified as indirect methods for regulating the environment (Poskrobko, 2007, p. 152). Economic instruments offer more flexibility as they provide firms or individuals greater freedom about how to adapt to economic incentives.

The most important function of economic instruments for environmental protection is an incentive function which consists in providing incentives for polluters to improve the use of environmental assets and resources. Under some conditions, these instruments allow achieving environmental policy objectives at the lowest social cost. Economic instruments may fulfil several other functions, namely (Poskrobko, 2007, p. 154):

- a redistributive function which consists in gathering and allocating funds for environmental investments,

- a fiscal function which consists in gathering budget revenues,

- an information function which consists in giving information about significant environmental risks and about the need of appropriate behaviour of agents.

Classification and a brief description of economic instruments which can be used for environmental protection are shown in Table 1. 
Table 1. Types of economic instruments used in environmental protection

\begin{tabular}{|c|c|}
\hline $\begin{array}{l}\text { Type or group of eco- } \\
\text { nomic instruments }\end{array}$ & General characteristics \\
\hline Financial incentives & $\begin{array}{l}\text { Different forms of financial assistance inducing polluters to act } \\
\text { in a more environmentally friendly way. Environmental subsidies } \\
\text { are implemented through grants from state budget or earmarked } \\
\text { funds, foreign aid and tax exemptions. }\end{array}$ \\
\hline $\begin{array}{l}\text { Environmental charges } \\
\text { and taxes }\end{array}$ & $\begin{array}{l}\text { Prices to be paid for pollution and degradation of natural re- } \\
\text { sources and environment. } \\
\text { Environmental charges should be requited. In practice, it is dif- } \\
\text { ficult to identify the differences between environmental charges } \\
\text { and taxes. }\end{array}$ \\
\hline $\begin{array}{l}\text { Administrative penal- } \\
\text { ties }^{\text {a) }}\end{array}$ & $\begin{array}{l}\text { Penalties for illegal activities, violating environmental regula- } \\
\text { tions. }\end{array}$ \\
\hline Deposit-refund systems & $\begin{array}{l}\text { Surcharges on the price of polluting products. When pollution } \\
\text { is avoided by returning the residuals of the product for reuse, } \\
\text { neutralization or proper disposal, a refund of the surcharge is } \\
\text { granted. }\end{array}$ \\
\hline Financial security & $\begin{array}{l}\text { Secure claims for damages and its environmental effects in the } \\
\text { result of business operations. This group of instruments includes: } \\
\text { performance bonds and environmental insurance. } \\
\text { Performance bonds are payments to environmental authorities } \\
\text { which take place prior to an activity that is potentially environ- } \\
\text { mentally harmful. These bonds are refunded if environmental } \\
\text { regulations are met. } \\
\text { Environmental insurance consists in transferring the civil liability } \\
\text { for the environmentally adverse effects to the insurance company. }\end{array}$ \\
\hline $\begin{array}{l}\text { Instruments based on } \\
\text { market transactions }\end{array}$ & $\begin{array}{l}\text { Instruments that create new markets. This group of instruments } \\
\text { includes: tradable allowance schemes, Joint Implementation, } \\
\text { Clean Development Mechanisms. } \\
\text { Tradable allowance scheme consists in granting permission (in } \\
\text { the form of tradable allowances) to interfering with the environ- } \\
\text { ment. The allowances can be traded between parts. } \\
\text { Joint Implementation (JI) and Clean Development Mechanisms } \\
\text { (CDM) are used to reduce or avoid the emissions of greenhouse } \\
\text { gases, or to capture carbon dioxide. These are the projects carried } \\
\text { by a country with an emission reduction or limitation commit- } \\
\text { ment under the Kyoto Protocol on a territory of other country } \\
\text { with such commitment (JI) or on a territory of a country without } \\
\text { such commitment (CDM). }\end{array}$ \\
\hline
\end{tabular}

a) Environmental penalties are classified by some authors as legal instruments.

Source: Poskrobko, 2007, pp. 152-165; Fiedor, Graczyk, 2002, pp. 293--335; Speck, Andersen, Nielsen, Ryelund, Smith, 2006, p. 20-23; Górka, 1993, p. 97. 


\section{General characteristics of the Polish system OF ECONOMIC INSTRUMENTS USED IN THE ENVIRONMENTAL POLICY}

Economic instruments used in environmental protection have been used in Poland since the 1960s. At that time, fines for water and air pollution, charges for extraction of sand and gravel from state waters and charges for alternative use of agricultural land were introduced into the Polish legislation. In subsequent years, the catalogue of fines and charges used in environmental protection has been gradually expanded into many different types of contamination (see Radecki, 2002, pp. 9-17).

Since the introduction of environmental charges and fines, these instruments have been used to finance environmental investments. The revenues from these charges and fines have been earmarked for environmental funds ${ }^{1}$ and the funds have been providing environmental subsidies. The current Polish system of environmental funds (especially funds for environmental protection and water management) is one of the most sophisticated systems of extra-budgetary environmental funds in the European countries. Earmarked funds provide financial assistance to local governments and firms in the form of grants and soft loans. This assistance plays an important role in promoting technological progress in environmental protection (especially integrated technologies and energy saving technologies).

The Polish system of economic instruments for environmental protection was significantly expanded after 2001 to include new instruments (used mainly in Western European countries) such as deposit-refund systems and product charges levied on goods causing problems in waste management. The significant development concerning the use of economic instruments in environmental policy was the launch of the carbon dioxide emission trading system in 2006. This EU-wide system is one of the tools for the European Union to achieve the targets of the Kyoto Protocol. Another tool is Joint Implementation, a mechanism used to reduce greenhouse gas emissions. By the end of April 2009, twelve Joint Implementation projects in Poland had been approved (mainly in the field of renewable energy and energy efficiency $)^{2}$.

A few years ago, a tradable certificate scheme was launched in Poland. This scheme can be treated as an economic instrument to be used in environmental policy. It consists in property rights trading. These rights are carried by certificates which prove that certain electricity is generated using renewable energy

${ }^{1}$ It is worth noting that Protection and Shaping of the Environment Act of 1980 (remained in force until 2001) classified environmental funds as economic instruments for environmental protection (Draniewicz, 2005, p. 80).

${ }^{2}$ Mechanizm wspólnych wdrożeń (JI) (2009), http://kashue.eu/serwis/index.php?page=ji (10th of September). 
sources (green certificates) or using cogeneration (red certificates). The property rights carried by certificates are tradable commodities.

After the introduction of the instruments that have created new markets, the Polish system of economic instruments has become similar to the systems existing in other European Union countries. However, there are still some differences in the functioning of environmental policy tools in Poland and the old EU countries. The differences are related to, inter alia, specific political, economic and legal-institutional systems in different countries (Fiedor, Stodulski, 2003, p. 99). Certain distinctive features of the Polish system of environmental instruments are sophisticated environmental charges (levied on many different substances emitted into environment and on a very large number of minerals) and environmental penalties, which are not common in Western European countries (see Vos, Barde, Mountford, 1999, p. 44).

\section{Changes in the Polish system of economic instruments USED IN ENVIRONMENTAL PROTECTION}

Many types of economic instruments are used in Poland. However, some instruments (especially environmental insurance) could be more widely used in the Polish environmental policy. Environmental insurance is applied in many Western European countries. In Poland we can talk only about the first phase of development: there are only two insurance products related to environmental damage on the Polish insurance market (Panasiewicz, 2005, pp. 106-107). Implementation of environmental insurance could benefit both insurance companies (by expanding the range of services they could attract new customers) and agents who could reduce the risk of business (Panasiewicz, 2005, p. 107).

A desirable development concerning the Polish system of economic instruments is to levy environmental taxes or charges on some ecologically harmful products, such as detergents, means of production used in agriculture and solvents (Fiedor, Famielec, Górka, Graczyk, Poskrobko, Stodulski, Żylicz, 2003, p. 361). Such fiscal measures already exist in some European countries, for instance, in Denmark and Sweden.

The systems of environmental charges and taxes applied in Poland and in other European Union member countries will certainly be influenced by the Community legislation. For example, the European Commission Communications show the need of harmonization of passenger car related taxes or landfill taxes. The harmonization of landfill taxes would prevent shipment of waste to countries with lower taxes in waste management. The European Union member countries have limited freedom in determining environmental levies which induce polluters to act in a more environmentally friendly way. For example, it refers to the allowable intensity of state aid in the form of exemptions from 
environmental taxes and charges, and to tax rates on energy products which shouldn't be lower than minimum levels of taxation specified in Directive 2003/96/EC .

The entry into force of Directive 2003/96/EC is considered - next to the launch of the European Union emission trading scheme - as the most significant development concerning the use of economic instruments in the European Union in recent years (Speck, Andersen, Nielsen, Ryelund, Smith, 2006, p. 9). The provisions of this directive had the greatest implications for the energy taxation in the Central and Eastern European countries, where the rates of tax fuels are quite low. The rates of taxes levied on energy carriers in Poland (except the tax rates applied to coal and coke) are currently higher than levels of taxation specified in Directive 2003/96/EC. Despite this, the tax burden on energy measured by the ITR on energy is relatively low (table 2 ). This could be a reason to make major changes to the energy carriers taxation system in Poland. This system could reflect better the objectives of energy policy and climate change policy.

Table 2. Tax burden on energy (in euro per tonne) in Poland and other European Union countries in 2000 and 2006

\begin{tabular}{|l|c|c|}
\hline ITR on energy & 2000 & 2006 \\
\hline Czech Republic & 55.9 & 103.3 \\
\hline Denmark & 313.7 & 329.2 \\
\hline Germany & 192.7 & 209.7 \\
\hline Italy & 248.7 & 246.2 \\
\hline Lithuania & 58.0 & 83.4 \\
\hline Poland & 59.2 & 101.4 \\
\hline Sweden & 182.0 & 217.9 \\
\hline United Kingdom & 249.5 & 239.7 \\
\hline EU-25 average & 128.3 & 155.6 \\
\hline
\end{tabular}

Source: Taxation Trends in the European Union (2009), Eurostat, Luxemburg, p. 122.

Changes in the taxation of energy products (e.g., consisting in an increase in excise duty levied on certain fuels) can be an element of an environmental tax reform which involves a replacement of 'traditional' taxes by taxes with the objective of improving the state of the environment (Wallart, 1999, p. 147). Such a reform is sometimes treated as a kind of economic instrument used in

${ }^{3}$ Council Directive 2003/96/EC of 27 October 2003 restructuring the Community framework for the taxation of energy products and electricity (OJ L 283, 31.10.2003).

${ }^{4}$ Implicit tax rate (ITR) on energy is a ratio of energy tax revenues to final energy consumption. Energy taxes include taxes on energy products used for both transport and stationary purposes. The final energy consumption is expressed as thousands of tons of oil equivalent $\left(1 \mathrm{TOE}=10 \cdot 10^{6} \mathrm{kcal}=10 \mathrm{Gcal}=41.87 \mathrm{GJ} / \mathrm{Mg}\right)$. 
environmental protection. Western European countries implemented 'green' tax reforms in the 1990s. More recently, such reforms have been implemented in Estonia, where the increases of excise duties on energy have been used to finance substantial cuts of income taxes ${ }^{5}$. It should be noted that environmental tax (fiscal) reform is also a reform where there is a removal of environmentally harmful subsidies. There are some environmentally harmful subsidies in Poland: for example, there is an exemption from excise duty applied to coal and coke used as heating fuels while some other energy carriers are taxed ${ }^{6}$.

The desirable development concerning the energy taxation in Poland is the implementation of carbon tax (a tax levied on emissions of carbon dioxide or on carbon content of fuels). There has been an interest in such taxes in Poland since the 1990s. A carbon charge is applied in Poland, but its rate is very low: in 2009 the rate of the charge was around 0.07 EUR per tonne of carbon dioxide, while the rate of carbon tax in Sweden is significantly higher than 100 EUR $^{7}$. Sweden, which held the Presidency of the Council of the European Union during the second half of 2009, encouraged the EU member states to introduce carbon taxes. Sweden is supported by France, which has already taken some steps to implement a domestic tax on carbon dioxide emissions in 2010. The carbon tax will be levied on households and companies (businesses covered by the European Union emission trading system will be exempted from the tax). France also calls for a border carbon tax on imports from outside the European Union (Hollinger, 2009).

One can certainly expect a further development of economic instruments based on market transactions in Poland during the oncoming years. The changes or developments in terms of energy taxation could consist in including new sectors into the European Union emission trading system (e.g., aviation as from $2012^{8}$ ). The Directive $2009 / 29 / \mathrm{EC}^{9}$ is essential for the functioning of the emission trading system. The Directive has been published as a part of the ClimateEnergy Legislative Package designated to achieve objectives approved in 2007 by the European Council of fighting the climate change. The Directive establishes a general rule that emission allowances should be auctioned from 2013 onwards. However, some exceptions from that rule are possible. The exceptions

${ }^{5}$ Taxation Trends in the European Union (2009), Eurostat, Luxemburg, p. 115.

${ }^{6}$ Dybiec (2000) had attempted to identify environmentally harmful subsidies from the viewpoint of Polish environmental policy.

${ }^{7}$ Carbon charges or taxes are applied also in Denmark, Finland, Norway and Slovenia.

${ }^{8}$ Directive 2008/101/EC of the European Parliament and of the Council of 19 November 2008 amending Directive 2003/87/EC so as to include aviation activities in the scheme for greenhouse gas emission allowance trading within the Community (OJ L 8, 13.1.2009).

${ }^{9}$ Directive 2009/29/EC of the European Parliament and of the Council of 23 April 2009 amending Directive 2003/87/EC so as to improve and extend the greenhouse gas emission allowance trading scheme of the Community (OJ L 140, 5.6.2009). 
include, inter alia, the Polish energy sector which would receive up to $70 \%$ of emission allowances free of charge.

There will be a new instrument in Poland, called a white certificate system, to encourage enterprises to implement energy-saving initiatives and to reduce carbon dioxide emissions (Żmijewski, 2007, p. 14). This mechanism is included in the draft of the Energy Efficiency Act which implements Directive 2006/32/ $\mathrm{EC}^{10}$. The Polish model has got to be based on three pillars (Żmijewski, 2007, p. 14; Szpiganowicz, 2008, p. 16):

1. Investors' declarations in the field of production, transmission and distribution and the final use of energy. These declarations will entitle one to apply for certificates. Energy audits which estimate ex ante energy savings constitute the basis for issuing the white certificates.

2. Tenders for the right to issue white certificates. Entities which declare the best effects of energy saving initiatives win the tender. It results in the issue and registration of specific number of certificates. White certificates are tradable.

3. Operations of the Polish Power Exchange. Power Exchange organizes trading in property rights arising from certificates.

Energy companies selling electricity, heat and natural gas to end users that are already connected to the grid are to obtain remit (redeem) certificates from the Energy Regulatory Office ${ }^{11}$. Companies which fail to remit the certificates pay the replacement fee. The Polish system is innovative (comparing with the systems applied in other European countries) because it includes not only the investments leading to an increase in energy efficiency by end-users, but also to investments leading to an increase of efficiency in generating electricity and heat and investments leading to a reduction of losses incurred in the transmission and distribution of electricity, heat and gas.

In 2010 Poland has to launch the emission trading scheme for sulphur dioxide and nitrogen oxides emissions from large combustion plants ${ }^{12}$. The new instrument should contribute to achieving the emission ceilings for $\mathrm{SO}_{2}$ and $\mathrm{NO}_{x}$ emissions specified in the Directive $2001 / 80 / \mathrm{EC}^{13}$ and the Treaty about the accession of the Republic of Poland to the European Union. The draft of the act which has to regulate emission trading system assumes that the manager of large combustion plant, who exceeds the annual limits of sulphur dioxide and nitrogen

${ }^{10}$ Directive 2006/32/EC of the European Parliament and of the Council of 5 April 2006 on energy end-use efficiency and energy services and repealing Council Directive 93/76/EEC (OJ L 114, 27.4.2006).

${ }^{11}$ Energy Efficiency Act (draft, 16th of July 2009).

${ }^{12}$ System of balancing and accounting for emissions of sulphur dioxide (SO2) and nitrogen oxides (NOx) from large combustion plants act (draft, 17th of July 2009).

${ }^{13}$ Directive 2001/80/EC of the European Parliament and of the Council of 23 October 2001 on the limitation of emissions of certain pollutants into the air from large combustion plants (OJ L 309, 27.11.2001). 
oxide emissions (calculated on its own) will have to buy a specific number of emission allowances or pay the replacement fee to the National Fund for Environmental Protection and Water Management. Operators of large combustion plants can trade emission allowances. It is worth mentioning that emission trading schemes for sulphur dioxide and nitrogen oxides emissions have already been in existence in Slovakia and in the Netherlands for several years.

In previous years, the desirable development concerning the use of economic instruments in Poland was the extension of deposit-refund systems to include some new products. The current deposit-refund systems apply to toxic or mutagenic chemicals packages and acid-lead accumulators ${ }^{14}$. In the European Union countries deposit-refund systems apply to products like tyres (Denmark), passenger cars (Estonia, Spain, Sweden) or different types of batteries and accumulators (Denmark) ${ }^{15}$. Extension of the deposit-refund systems applied in Poland doesn't seem likely - most of products causing problems in waste management are subject to environmental charges. Introduction of a deposit-refund system instead of charging could reduce revenues of earmarked funds.

While implementing economic instruments, Poland can use the experience gained in applying such instruments in other countries. Reports published by the European Environment Agency and the European Commission Communications give several examples of effective tools for environmental protection. The examples include: the London congestion charge (a fee that is levied on motorists entering the Central London area), the Norwegian pesticide tax differentiated according to environmental and human and animal health risks, and 'habitat banking', a system mainly used in the United States ${ }^{16}$. The latter instrument is based on the idea of tradable permits. It is an economic instrument for biodiversity protection. Generally speaking, it works as follows: if a developer wants to destroy a habitat, he has to purchase a permit to do so, from someone who has created a piece of valuable habitat elsewhere. It does not matter that there are some other areas of application of tradable permits, such as: biodegradable waste management (United Kingdom) and the fishery (the Netherlands).

${ }^{14}$ Since 2002 there has been a deposit fee for acid-lead accumulators. Despite its name used by the legislature, the instrument cannot be treated as a fee, because the fee should be non-refundable.

${ }^{15}$ The OECD/EEA Database on Instruments used for Environmental Policy and Natural Resources Management (2009), http://www2.oecd.org/ecoinst/ queries/index.htm (10th of September).

${ }^{16}$ Market-Based Instruments for Environmental Policy in Europe (2005), European Environmental Agency, Copenhagen, s. 48 i 72; Green Paper on Market-Based Instruments for Environment and Related Policy Purposes, KOM(2007) 140 final. 


\section{Conclusions}

Economic instruments have played an important role in the Polish environmental policy for several dozen years. Environmental charges and fines are the instruments with the longest tradition in this policy. These charges and fines are used to finance (in the form of subsidies and grants from earmarked funds) different environmental investments. There are also some new, interesting economic instruments like deposit-refund systems, tradable energy certificates and the European Union emission trading scheme which is the largest multi-national, emissions trading scheme in the world.

Despite a wide range of economic instruments used in the Polish environmental policy, there are some other instruments or mechanisms which can be introduced in Poland. These include, inter alia, environmental insurance products or environmental tax reform.

The analysis also suggests that the current and further development of economic instruments used in Poland is going to be strongly influenced by the European Union legislation. This is particularly evident in the case of economic instruments based on market transactions, particularly those which are related to climate changes.

\section{REFERENCES}

Council Directive 2003/96/EC of 27 October 2003 restructuring the Community framework for the taxation of energy products and electricity (OJ L 283, 31.10.2003).

Directive 2001/80/EC of the European Parliament and of the Council of 23 October 2001 on the limitation of emissions of certain pollutants into the air from large combustion plants (OJ L 309, 27.11.2001).

Directive 2006/32/EC of the European Parliament and of the Council of 5 April 2006 on energy end-use efficiency and energy services and repealing Council Directive 93/76/EEC (OJ L 114, 27.4.2006).

Directive 2008/101/EC of the European Parliament and of the Council of 19 November 2008 amending Directive 2003/87/EC so as to include aviation activities in the scheme for greenhouse gas emission allowance trading within the Community (OJ L 8, 13.1.2009).

Directive 2009/29/EC of the European Parliament and of the Council of 23 April 2009 amending Directive 2003/87/EC so as to improve and extend the greenhouse gas emission allowance trading scheme of the Community (OJ L 140, 5.6.2009).

Draniewicz B., (2004), Ocena charakteru prawnego opłaty depozytowej, „Ochrona Środowiska. Przegląd", no. 3.

Draniewicz B., (2005), Przeglad wybranych instrumentów ochrony środowiska, „Prawo i Środowisko", no. 4.

Dybiec M., (2005), Subsydia szkodliwe dla środowiska w Polsce - próba identyfikacji, Instytut na rzecz Ekorozwoju (unpublished paper).

Energy Efficiency Act (draft, 16th of July 2009).

Fiedor B., Famielec J., Górka K., Graczyk A., Poskrobko B., Stodulski W., Żylicz T., (2003), 
Koncepcja modyfikacji systemu instrumentów ekonomicznych dla ochrony środowiska, The project financed with the funds of the National Fund for Environmental Protection and Water Management, ordered by the Minister of Environment, Akademia Ekonomiczna in Wrocławiu, Wrocław.

Fiedor B., Graczyk A., (2002), Ogólna charakterystyka instrumentów ekonomicznych w ochronie środowiska, [in:] B. Fiedor (ed.), Podstawy ekonomii środowiska i zasobów naturalnych, Wydawnictwo C.H. Beck, Warszawa.

Fiedor B., Stodulski W., (2003), Instrumenty ekonomiczno-finansowe ochrony środowiska w krajach Unii Europejskiej, w: T. Borys (ed.), Finansowanie ochrony środowiska $w$ Polsce $w$ kontekście standardów Unii Europejskiej, Wojewódzki Fundusz Ochrony Środowiska i Gospodarki Wodnej we Wrocławiu, Wrocław.

Górka K., (1993), Analiza porównawcza opłat i podatków ekologicznych w Polsce i w krajach gospodarki rynkowej, [in:] K. Górka (red.), Ekonomika ochrony środowiska naturalnego, Biblioteka „Ekonomia i Środowisko” No. 14, Cracow.

Green Paper on Market-Based Instruments for Environment and Related Policy Purposes, $\operatorname{COM}(2007) 140$ final.

Hollinger P., (2009), Sarkozy Calls for Carbon Tax on Imports, http://www.ft.com/cms/s/0/ a5fb6084-9e32-11de-b0aa-00144feabdc0.html (12th of September).

Market-Based Instruments for Environmental Policy in Europe (2005), European Environmental Agency, Copenhagen.

Mechanizm wspólnych wdrożeń (JI) (2009), http://kashue.eu/serwis/index.php?page=ji (10th of September).

Opschoor J. B., Vos H. B. (1990), Instrumenty ekonomiczne dla ochrony środowiska, OECD, MOŚZNiL, Warszawa.

Panasiewicz A., (2005), Możliwości rozwoju ubezpieczeń ekologicznych w Polsce na tle niemieckiego rynku ubezpieczeń ekologicznych, [w:] T. Borys (red.), „Gospodarka a Środowisko", Prace Naukowe nr 1075 Akademii Ekonomicznej we Wrocławiu, Wydawnictwo Akademii Ekonomicznej we Wrocławiu, Wrocław.

Poskrobko B., (2007), Instrumenty ekonomiczne, [in:] B. Poskrobko (ed.), Zarzqdzanie środowiskiem, PWE, Warszawa.

Radecki W., (2002), Środki finansowo-prawne. Komentarze do ustawy-Prawo ochrony środowiska, Towarzystwo Naukowe Prawa Ochrony Środowiska, Wrocław.

Śleszyński J., (2000), Ekonomiczne problemy ochrony środowiska, Aries, Warszawa.

Speck S., Andersen M., Nielsen H., Ryelund A., Smith C., (2006), The Use of Economic Instruments in Nordic and Baltic Environmental Policy 2001-2005, Nordic Council of Ministers, Copenhagen.

System of balancing and accounting for emissions of sulphur dioxide (SO2) and nitrogen oxides (NOx) from large combustion plants act (draft, 17th of July 2009).

Szpiganowicz P., (2008), Bilans osiagnięć planowanego systemu, ,Energia Elektryczna”, No. 3.

Taxation Trends in the European Union (2009), Eurostat, Luxemburg.

The OECD/EEA Database on Instruments used for Environmental Policy and Natural Resources Management (2009), http://www2.oecd.org/ecoinst/ queries/index.htm (10th of September).

Vos H., Barde J.-P., Mountford H., (1999), Economic Instruments for Pollution Control and Natural Resources Management in OECD Countries: A Survey, OECD, Paris.

Wallart N., (1999), The Political Economy of Environmental Taxes, Edward Elgar Publishing Limited, Cheltenham.

Żmijewski K., (2007), Białe certyfikaty - instrukcja obstugi systemu, „Czysta Energia”, No. 11. 


\section{KIERUNKI ZMIAN W FUNKCJONOWANIU INSTRUMENTÓW EKONOMICZNYCH ochrony Środowiska w Polsce}

Słowa kluczowe: polityka ochrony środowiska, instrumenty ekonomiczne ochrony środowiska, opłaty i podatki ekologiczne, handel uprawnieniami do emisji

Abstrakt: Celem artykułu jest przedstawienie stanu polskiego systemu instrumentów ekonomicznych w kontekście doświadczeń innych krajów europejskich (zwłaszcza krajów Unii Europejskiej) oraz wskazanie kierunków zmian w zakresie funkcjonowania tych instrumentów w najbliższych latach. W opracowaniu wykorzystano dostępną literaturę, raporty przygotowane na zlecenie Ministerstwa Środowiska, a także opracowania Organizacji Współpracy Gospodarczej i Rozwoju oraz Europejskiej Agencji Środowiska. Z przeprowadzonej w artykule analizy wynika, że instrumenty ekonomiczne ochrony środowiska stosowane są w Polsce na dość dużą skalę. Szczególne znaczenie w polskiej polityce ekologicznej spełniają już od kilkudziesięciu lat opłaty i kary przeznaczane na celowe fundusze ekologiczne. Od kilku lat funkcjonują w Polsce również inne, interesujące instrumenty ekonomiczne, takie jak: depozyty ekologiczne, system zbywalnych praw majątkowych wynikających ze świadectw pochodzenia energii oraz handel uprawnieniami do emisji dwutlenku węgla. Do pożądanych kierunków zmian w funkcjonowaniu instrumentów ekonomicznych w polskiej polityce ochrony środowiska zaliczono między innymi: rozszerzenie zakresu stosowania opłat i podatków ekologicznych, upowszechnienie ubezpieczeń ekologicznych oraz przeprowadzenie ekologicznej reformy podatkowej. 